DARIUSZ JAROSZ

https://orcid.org/0000-0002-7882-8532

Instytut Historii im. Tadeusza Manteuffla Polskiej Akademii Nauk

\title{
OBRAZY OKRUCIEŃSTWA: WSTĘP DO BADAŃ NAD TRAKTOWANIEM BYDEA I TRZODY CHLEWNEJ W POLSCE LUDOWEJ NA PRZEŁOMIE LAT PIĘĆDZIESIĄTYCH I SZEŚĆDZIESIĄTYCH XX W.
}

Zarys treści: Artykuł jest próbą naszkicowania obrazów okrucieństwa wobec zwierząt rzeźnych w Polsce na przełomie lat pięćdziesiątych i sześćdziesiatych XX w. Podstawą źródłową poczynionych ustaleń były przede wszystkim nieliczne dokumenty archiwalne, jakie udało się odnaleźć w Archiwum Akt Nowych i Archiwum Instytutu Pamięci Narodowej. Autor starał się ustalić, na jakich etapach życia zwierząt okrucieństwo ludzi przejawiało się najsilniej, na czym ono polegało i jakie przybierało formy.

The content outline: The article seeks to outline the images of cruelty towards animals for slaughter in Poland at the turn of the 1950s and the 1960s. The source materials constituting the basis for the research are primarily the scarce archival documents found at the Archives of Modern Records and the Archive of the Institute of National Remembrance. The author seeks to determine at which stage of the animals' life the level of cruelty was the highest, how the abuse was manifested, and what forms it took.

Słowa kluczowe: animal studies, okrucieństwo wobec zwierząt, zwierzęta rzeźne, rzeźnie, Polska Ludowa

Keywords: animal studies, animal abuse, animals for slaughter, slaughterhouses, Polish People's Republic

W historiografii dotyczącej problematyki społecznej w Polsce w latach 1945-1989 kwestia stosunku do zwierząt, w tym przejawów okrucieństwa wobec nich, jest tematem zupełnie zapoznanym. To samo można powiedzieć w zasadzie o dorobku polskiej humanistyki. Tzw. animals turn w humanistyce światowej, zainicjowany w latach siedemdziesiatych 
XX w., nie znalazł w Polsce swych naukowych admiratorów ${ }^{1}$. Na ile zdecydowały o tym pozamerytoryczne uwarunkowania, a na ile pozbawione „drugiego dna” zaniedbania - trudno powiedzieć. Bez względu na przyczyny, mimo pierwszych ,jaskółek” zmian tego stanu rzeczy ${ }^{2}$, badacz pragnący wypełnić tę bynajmniej niepolityczna „biała plamę” w polskiej humanistyce stoi przed zadaniem pionierskim i skomplikowanym. Wynika to przede wszystkim z trudności uzyskania dostępu do odpowiednich źródeł. Władze centralne organizacji społecznych, których statutowym obowiazkiem było zajmowanie się losem zwierząt (Towarzystwo Opieki nad Zwierzętami, Polski Związek Łowiecki), twierdza, że nie posiadaja takich dokumentów z okresu przed 1989 r. Poszukiwania w archiwach państwowych sa skomplikowane $\mathrm{z}$ tego powodu, że akta dotyczące losu zwierząt w PRL są rozproszone, często były brakowane, a informacje dotyczące okrucieństwa wobec „braci mniejszych” kamuflowane, formułowane w ezopowych zwrotach oficjalnych sprawozdań urzędowych.

Czy jesteśmy więc w sytuacji naukowego imposybilizmu? Nie do końca. Prezentowany szkic ma ambicje „wydeptania” waskiej (jak na razie) ścieżki, która wskazuje pewien kierunek badań i poszukiwań źródłowych. Jego głównym celem jest odpowiedź na pytanie, gdzie można znaleźć przekazy pozwalające na przynajmniej naszkicowanie obrazów okrucieństwa wobec zwierząt rzeźnych i jaki jest wizerunek ich cierpień w tych dokumentach.

Wybór tej kategorii zwierząt wynikał przede wszystkim z przekonania, że ze względu na ich masowe zabijanie w celach konsumpcyjnych ślady źródłowe dotyczące ich traktowania winny być stosunkowo liczne w aktach wielu instytucji społecznych i państwowych. Wszak świnie czy krowy odbywały dość długą i jak się okazało bolesną tak fizycznie, jak psychicznie drogę od punktu skupu do rzeźni.

Podstawa źródłowa poczynionych ustaleń były: publicystyka prasowa oraz dokumenty zgromadzone w centralnych archiwach i urzędach.

${ }^{1}$ Szerzej o zwrocie ku zwierzętom w humanistyce, w tym o stanie badań w Polsce, zob. M. Bakke, Studia nad zwierzętami. Od aktywizmu do akademii i $z$ powrotem?, „Teksty Drugie” 2011, nr 3, s. 193-204; Animal Revolution. Changing Attitudes toward Speciesism, Oxford 2000; E. Domańska, Historia w kontekście posthumanistyki, „Historyka. Studia Metodologiczne” 45, 2015, s. 19-20; K. Nowak, Animal studies - wyzwanie dla historiografii?, https://histmag.org/Animal-studies-wyzwanie-dla-historiografii-3208 (27 II 2019).

2 Zwierzęta i ich ludzie. Zmierzch antropocentrycznego paradygmatu, red. A. Barcz, D. Łagodzka, Warszawa 2015; Człowiek $w$ relacji do zwierzat, roślin i maszyn $w$ kulturze, t. 1: Aspekt posthumanistyczny i transhumanistyczny, t. 2: Od humanizmu do posthumanizmu, red. J. Tymieniecka-Suchanek, Katowice 2014. 
Wśród tych drugich kwerendzie poddane zostały m.in. akta ministerstw: Rolnictwa i Reform Rolnych, Rolnictwa, a także Najwyższej Izby Kontroli oraz Towarzystwa Ochrony Zwierząt.

Niespodziewanie interesująca okazała się kwerenda akt Ministerstwa Spraw Wewnętrznych w Archiwum Instytutu Pamięci Narodowej. Okazało się, że z powodu kontroli przeprowadzanych przez ten resort zwiazanych z budząca wątpliwości działalnością organizacyjną Towarzystwa Opieki nad Zwierzętami (TOnZ) ministerstwo zgromadziło wcale pokaźne dossier dotyczące tego stowarzyszenia, w tym zupełnie unikatowe sprawozdania z kontroli rzeźni z lat sześćdziesiątych XX w. To niezwykle wstrzasajacca lektura, ale niezmiernie ważna, poświadczająca bowiem z „pierwszej ręki” to, jak daleko posunięte było okrucieństwo wobec zwierząt, które tam trafiały.

Chronologicznie rozważania zostały ograniczone w zasadzie do okresu od drugiej połowy lat czterdziestych do początków lat 60 . XX w., z którego pochodzi większość zgromadzonych dokumentów. Dokonane ustalenia nie dają podstaw do określenia dynamiki opisywanych praktyk wobec zwierząt. Trudno na ich podstawie odpowiedzieć na pytanie, jak stosunek do nich zmieniał się w czasie. Można jednak określić, na jakich etapach drogi między miejscem hodowli a rzeźnią zwierzęta cierpiały najbardziej i jakiego rodzaju były to cierpienia.

\section{Prolog: zwierzęta i ich właściciele}

Okrucieństwo wobec zwierząt było zjawiskiem, które dostrzegano w dyskursie władz powojennej Polski już od drugiej polowy lat czterdziestych. Nieprzypadkowo wszak już w 1948 r. minister administracji publicznej wystapił do wojewodów, prezydentów miast Warszawy i Łodzi, starostów powiatowych, prezydentów miast, burmistrzów i wójtów z zaleceniem, aby dla zwiększenia skuteczności w zwalczaniu znęcania się nad zwierzętami zaostrzyć „na pewien okres czasu [sic!]” represje karne w stosunku do osób wykraczających poza odpowiednie przepisy w tej sprawie, tj. rozporządzenie z 22 III 1928 r. Postulował zaniechanie karania w trybie nakładania grzywien, a zamiast tego sporządzanie doniesień i penalizację $\mathrm{w}$ trybie karno-administracyjnym ${ }^{3}$.

${ }^{3}$ Archiwum Instytutu Pamięci Narodowej w Warszawie (dalej: AIPN), sygn. 1550/2971, Minister Administracji Publicznej do wojewodów, prezydentów miast Warszawy i Łodzi, starostów powiatowych, prezydentów miast, burmistrzów i wójtów, Warszawa, 20 XI 1948 r., k. nlb. Chodziło o Rozporządzenie Prezydenta Rzeczypospolitej z 22 III 1928 r. o ochronie zwierzą; Dz. U., nr 36, poz. 332. 
Dla wielu zwierząt początek ich cierpień związany był ze sposobem, w jaki traktowali je ich właściciele. W przypadku gospodarstw chłopskich zdarzało się, że były one nieodżywione. Najwięcej odnalezionych tego typu informacji nieprzypadkowo pochodzi z wczesnych lat pięćdziesiątych XX w., kiedy gospodarka rolna znalazła się w kryzysie wywołanym wprowadzaniem kolektywizacji. W piśmie warszawskiego Wojewódzkiego Zarządu Weterynarii z 1953 r. stwierdzano np., że na terenach poszczególnych powiatów odnotowywano coraz więcej upadków zwierząt, przeważnie bydła, które z tego powodu były poddane tzw. ubojowi z konieczności. Badania kliniczne wskazywały, że były to wypadki silnego osłabienia organizmu zwierzat z powodu braku składników mineralnych i białkowych w paszach, jakimi dysponowali chłopi ${ }^{4}$.

To wygłodzenie zwierząt wynikało przede wszystkim z trudności ze zdobyciem pasz, zwłaszcza w okresach nieurodzaju, ale nie tylko. Głodzenie w okresie kolektywizacji stawało się elementem strategii przystosowawczych do systemu obowiazkowych dostaw podstawowych artykułów rolnych. W tymże 1953 r. w powiecie Rawa Mazowiecka rozwinęła się hodowla cieląt o wyjątkowo niskiej wadze (tzw. szkieleciki). Utrzymywano je tylko dlatego, aby uzyskać dzięki nim odpowiednią zniżkę w dostawach obowiązkowych mleka. Po jej otrzymaniu cielęta były sprzedawane na wolnym rynku lub w ramach obowiązkowych dostaw $\mathrm{w}$ charakterze tzw. zamienników ${ }^{5}$. Trudno oszacować skalę tego procederu, ale jego stosowanie jest potwierdzone źródłowo.

\section{Skup i transport}

Kolejnym powodem cierpień bydła i trzody był sposób przeprowadzania ich skupu i transport do rzeźni (zakładów mięsnych). Nieliczne przekazy źródłowe, jakie dotąd udało się odnaleźć, prawdopodobnie dokumentują dużo szersza praktykę postępowania ze zwierzętami.

Już w latach czterdziestych prasa lokalna podnosiła ten problem. Dobry przykład stanowi artykuł w „Życiu Radomskim” z 1948 r. Jego autor opisywał okolice radomskiego targowiska miejskiego na ul. Wernera, gdzie w każdy czwartek odbywał się spęd zwierząt, traktowanych okrutnie: „1. Świnie i prosięta są pędzone przez przekupniów za pomoca

${ }^{4}$ Archiwum Zakładowe Ministerstwa Rolnictwa i Gospodarki Żywnościowej, Ministerstwo Rolnictwa, sygn. 4733, Prezydium Warszawskiej Wojewódzkiej Rady Narodowej, Wojewódzki Zarząd Weterynarii, Pruszków, 31 III 1953 r., k. 144.

${ }^{5}$ Sprawozdanie z wywiadu w indywidualnych gospodarstwach chłopskich siedmiu powiatów (koniec sierpnia 1953), „Biuletyn IER” 1953, nr 2, s. 3-35. 
kopniaków, mających zmusić zwierzęta do szybszego biegu w oznaczonym kierunku. 2. Małe cielaki powiązane powrozami, zrzuca się i wrzuca na wozy jak toboły, względnie pozostawia na pełnym słońcu w powrozach na przyległej łace. Biedne zwierzęta ledwie żywe z bólu (na skutek nieumiejętnego skrępowania) oraz pragnienia - ryczą beznadziejnie. 3. Krowy miast na postronkach, sa przesuwane z miejsca na miejsce swoista metoda ciagnięcia ... za ogon”6.

Ten opis koresponduje z treścią listu wysłanego do Polskiego Radia latem 1957 r., opisującego warunki skupu zwierząt dokonywanego przez Gminna Spółdzielnię „Samopomoc Chłopska” Krośniewice w pow. opoczyńskim. Krowy i cielęta zakupione od rolników 4 lipca tego roku, „tego samego dnia wieczorem odwieziono do miejsca przeznaczenia a świnie? No i cóź? Dziś jest 5 VII [19]57 r. Tuczniki około 170-180 sztuk zostały. Byłam na targowicy, która znajduje się w mieście. Dziś notowano temp[eraturę] 34 stopni. Trudno wytrzymać w cieniu. Jest ok. 18-ta, świnie znajdują się 2 dni na słońcu. Jak mnie poinformowano padło ich już ładne kilka sztuk. Obecnie przy mnie w ciagu 5 minut padło kilka sztuk. W chwili obecnej wszystkie świnie (tuczniki) leżą na pół żywe i nie daja prawie znaków życia. Pilnujący świń ob. K. nie wie, kiedy i gdzie zostaną zabrane. [...] Dogorywającym świniom przygląda się mnóstwo dzieci i dużo starszych osób, które patrzą na tę gospodarkę ze zgrozą". Zwierzęta zabrano dopiero po godz. 22, część nieprzytomnych wnoszono na ciężarówkę na dragach. Ich mięso nie nadawało się nawet do taniej jatki ${ }^{7}$.

Punkty skupu miały również inne wady. Roman B., obserwujący skup trzody chlewnej w Mrozach w pow. Mińsk Mazowiecki, w 1961 r. pisał do koła Ligi Ochrony Przyrody: „Rampa, na którą ładuje się trzodę chlewną na samochody jest za niska i brak jest pomostu, po którym by można świnie wprowadzać na samochód. Do przepędzenia trzody z rampy na samochody używa się wideł, bijąc świnie po grzbietach względnie kłując nimi, gdzie popadło w bestialski sposób"».

$\mathrm{Na}$ warunki skupu i transportu zwierząt zwracał uwage publicysta „Tygodnika Demokratycznego” w 1962 r. Jak ustalił, tylko na Lubelszczyźnie ok. 70\% skór zdjętych ze zwierząt rzeźnych nosiło ślady uszkodzeń mechanicznych, dyskwalifikujących je częściowo lub w całości jako

${ }^{6}$ JOTWAL, O czworonogach i dwunożnych okrutnikach, „Życie Radomskie”, 3 VII 1948.

7 Archiwum Ośrodka Dokumentacji i Zbiorów Programowych Telewizji Polskiej, sygn. 1050/21/1, Biuletyn nr 50, 12 VII 1957.

8 AIPN, sygn. 1585/22813, R. Budzyński, pracownik Narodowego Banku Polskiego do LOP koło Michalin, Warszawa, 16 XI 1962 r., k. 161. 
surowiec przemysłowy. Skóry były uszkodzone już na grzbietach zwierząt, co dowodziło niehumanitarnego postępowania z nimi ${ }^{9}$.

Jeden z opisów sposobu traktowania zwierząt rzeźnych już po opuszczeniu punktu skupu i transportowania do rzeźni sporządził członek Towarzystwa Opieki nad Zwierzętami w 1959 r. w liście nadanym w Gliwicach: „Transporty wszelkich zwierzat, przeznaczonych na rzeź, odbywają się tu na Górnym Śląsku w najokropniejszych warunkach, jakie w ogóle istnieć mogły kiedykolwiek na świecie. Na torach po różnych stacjach, przed i poza stacjami i w polu, stoja godzinami pociagi towarowe, w których zamknięte i ścieśnione są w nadmiernej ilości tak świnie, krowy, cielęta, owce, a nawet konie - w dodatku przywiązane w samych wagonach na króciutkich sznurkach, gdzie biedne zwierzęta nawet nie moga położyć się po kilkudniowym zamknięciu w wagonie towarowym". Jako przykład podawał transport zwierząt załadowany 15 kwietnia o godz. $11 \mathrm{w}$ Lublinie, który trafił do celu - do rzeźni w Mikołowie - 18 kwietnia. Jej personel rano tego dnia zabrał się do wyładowywania „głodnego, wychudzonego, wymęczonego i chorego żywca do zabicia”.

Autor listu wskazywał na jeszcze jednego „groźnego wroga” w czasie transportu - zbyt duży mróz lub upał: „W ubiegłym roku widziałem wiele sztuk żywca, który się dusił i musiał być zabity w drodze. To samo i w obecnej porze czeka transportowany żywiec. Zaznaczyć pragnę, że drugostronnie opisane fakty w czasie transportów odbywaja się z reguły co kilka dni, tj. raz na tydzień”. Winą obarczał władze kolejowe, które nie były w stanie zaplanować transportów żywca w sposób cykliczny ${ }^{10}$.

O brutalnym traktowaniu zwierząt w punktach skupu i podczas transportu pisała również w 1968 r. Wanda Falkowska, która została zaopatrzona przez Zarząd Główny TOnZ w dokumenty sporządzone w trakcie dokonywanych przez nie kontroli (tzw. akcja Upał). Publicystka „Prawa i Życia” cytowała fragmenty otrzymanych raportów: „Świnie przychodzą w blaszanych wagonach, ściany wagonu rozpalone, że ręką nie można dotknąć, a świnie żywcem usmażone”. „W zakładach mięsnych województwa katowickiego w transportach kolejowych i samochodowych nadesłanych z całego kraju, padło 161 sztuk świń, a w magazynach żywca tychże zakładów 266 świń, wszystko w dniach od 15 do 21 czerwca. Razem padło 427 świń, powodując straty w wysokości ponad półtora miliona złotych”. Autorka odnotowywała, że co roku skup był

${ }_{9}$ W. Wernic, Szkoła zdziczenia, „Tygodnik Demokratyczny” 1962, nr 50, s. 1.

${ }_{10}$ AIPN, sygn. 1585/22813, Członek TOZ do ZG TOZ w Polsce, Gliwice, 15 V 1959 r., k. 163 . 
nieprzygotowany do nadejścia ciepłych dni, nierównomierności dostaw bydła do punktów skupu, przewozu i uboju. W okresach zwiększonych dostaw powstawały zatory. Gdy w okresie upałów transport świń z Siemiatycz do rzeźni w Mysłowicach trwał trzy dni w jednym tylko transporcie zanotowano 170 wypadków śmierci zwierząt. W punktach skupu brakowało odpowiednich ramp, co powodowało brutalne ściaganie zwierząt $\mathrm{z}$ wozów, połączone nierzadko z maltretowaniem i okaleczeniem. Podczas transportu zwykle nie dbano o karmienie i pojenie zwierząt, docierały tam wyczerpane z głodu i pragnienia. Na stacjach kolejowych brakowało punktów do czerpania wody. Konwojenci nie dbali o to, „myśląc $\mathrm{w}$ duchu, że nie ma potrzeby aż tak cackać się z bydłem przeznaczonym przecież na rzeź"11.

Wiesław Wernic wskazywał w „Tygodniku Demokratycznym” w 1962 r. na inna ,głupotę": transport zwierząt przy temperaturze $-17^{\circ} \mathrm{C} \mathrm{w}$ nieprzygotowanych do takich warunków wagonach ${ }^{12}$.

Wiele cierpień, zawinionych przez człowieka, przeżywały zwierzęta transportowane za granicę. Świadczą o tym kontrole przeprowadzone przez NIK na granicznym punkcie weterynaryjnym w Zebrzydowicach w latach sześćdziesiątych. Część zwierząt docierała tam martwa lub w stanie niepozwalającym na eksport. Były one odłączane (wedle ówczesnej terminologii: „odładowywane”) od transportu. Winny one być odbierane przez zakłady mięsne, ale te niechętnie to czyniły. Z powodu braku właściwych pomieszczeń do przetrzymywania zwierząt chorych i miejsca do przeprowadzenia uboju z konieczności zabijania „dokonywano na rampie, obok której przejeżdżaja międzynarodowe pociagi osobowe"13. Lista braków tego punktu, odbijajacych się negatywnie na sposobie traktowania zwierząt, była znacznie szersza. Rampy zwierzęce w stosunku do rozmiarów eksportu były za małe, mieściły 20 wagonów, podczas gdy średnia dzienna transportów za rok 1965 wynosiła dwa razy więcej. Kanalizacja punktu była przestarzała i nie spełniała swojego zadania. Punkt wyposażony był w przestarzała sieć wodociagowa: co prawda wybudowano nowa, ale była nieczynna. Brakowało zupełnie tzw. konfiskatora na padlinę, gnojowni na nawóz wyrzucany z wagonów, pomieszczenia do przechowywania sztuk ubitych, kuchni

${ }^{11}$ W. Falkowska, Świńskie piekło, „Prawo i Życie” 1968, nr 20, s. 5.

${ }^{12}$ W. Wernic, dz. cyt., s. 1.

${ }_{13}$ Archiwum Akt Nowych w Warszawie (dalej: AAN), Najwyższa Izba Kontroli II (dalej: NIK II), sygn. 41/97, Protokół kontroli Głównego Granicznego Lekarza Weterynarii $\mathrm{w}$ Zebrzydowicach $\mathrm{z}$ siedzibą na dworcu towarowym PKP Zebrzydowice [...] przeprowadzonej w okresie od 4 do 12 maja 1967 przez starszego inspektora kontroli państwowej NIK lekarza wet. Tadeusz Kuligowskiego, b.d., k. 10. 
do przyrządzenia mleka w razie eksportu cieląt mlecznych. Woda używana do pojenia zwierząt była niezdatna do picia, niechlorowana, pochodziła z ujęcia rzecznego (Piotrówka). Remontu wymagał główny basen dezynfekcyjny ${ }^{14}$.

\section{Rzeźnie}

Zwierzęta po często wyczerpującym transporcie docierały do rzeźni. Tu wiele z nich doświadczało kolejnych okrucieństw.

Już z lat czterdziestych pochodzą informacje, że zwierzęta, które wycieńczone docierały do rzeźni, nie były często przez wiele dni pojone i karmione. Brak pasz wynikał często z ich niedostarczenia, mimo zgłaszanego zapotrzebowania ${ }^{15}$.

O tym, że sytuacja zwierząt w rzeźniach w niewielkim stopniu się poprawiała, świadcza sprawozdania pokontrolne NIK i TOnZ. Kontrolerzy NIK opisywali m.in. skutki spiętrzenia dostaw zwierząt przez rolników w listopadzie i grudniu 1962 r., wywołane brakiem pasz w okresie srogiej zimy. Ale paszy w odpowiedniej ilości nie miały również zakłady mięsne: „W wyniku zwiększonych dostaw żywca i nieprzygotowania Zakładów od strony zabezpieczenia w paszę, żywiec stał w Zakładach po kilka dni słabo karmiony lub w ogóle nie karmiony, jak np. w Zakładach Mięsnych we Chrzanowie. W zakładach tych w okresie 4.12 do 14.12. br. na skutek braku śruty i otrab nie karmiono trzody" ${ }^{2}$. Trudno nawet sobie wyobrazić, co się działo w sytuacji dziesięciodniowego pozbawienia pożywienia. W tychże zakładach przyjętą w październiku 1962 r. trzodę ulokowano w kojcach brudnych, niezdezynfekowanych i niezaścielonych, stąd też zwierzęta były zanieczyszczone kałem i nawozem. Niekarmione bydło znajdowało się w pomieszczeniach nadmiernie zagęszczonych ${ }^{17}$.

${ }_{14}$ Tamże, Prezydium Wojewódzkiej Rady Narodowej w Katowicach do Wojewódzkiego Lekarza Weterynarii w Katowicach, Zebrzydowice, 30 III 1966 r., k. 40-41.

${ }_{15}$ Zob. np. AAN, Towarzystwo Ochrony Zwierząt (dalej: TOZ), sygn. 24, Centralny Zarząd Przemysłu Mięsnego. Ekspozytura na Województwo Katowickie, Chorzowskie Zakłady Mięsne, Meldunek do Towarzystwa Ochrony Zwierząt w Katowicach, Chorzów, 18 XI 1950 r., k. nlb.

${ }^{16}$ AAN, NIK II, sygn. 33/282, Notatka służbowa sporządzona przez st. insp. Romana Kowacza na temat skutków nie podjęcia przez Centralę Przemysłu Mięsnego względnie Ministerstwo Przemysłu Spożywczego i Skupu odpowiednich skutecznych kroków w zakresie rozładowania dostaw żywca w okresie listopad-grudzień $1962 \mathrm{r}$. i zapewnienia paszy dla dostarczonego żywca do Zakładów Mięsnych, b.d., k. nlb.

17 Tamże, Protokół oględzin, Chrzanów, 20 X 1962 r., k. nlb. 
To oszczędzanie na karmieniu i pojeniu bydła było praktyka powszechną i codzienna, i to mimo ustalonych formalnie zasad, które obowiązywały w $1962 \mathrm{r}$. Zgodnie z nimi zwierzęta rzeźne przetrzymywane $\mathrm{w}$ magazynie winny być karmione według ustalonych norm dwa razy dziennie, o godz. 6 i 18, a tzw. głodówka przedubojowa miała trwać 12 godzin. Faktycznie w Zakładach Mięsnych w Białymstoku były przypadki przetrzymywania bydła skapo karmionego raz dziennie przez kilka dni ${ }^{18}$. Jeszcze gorzej było w Zakładach Mięsnych w Lublinie, gdzie w porozumieniu z lubelskim Powiatowym Przedsiębiorstwem Obrotu Zwierzętami Rzeźnymi od 1959 r. postanowiono znieść karmienie wieczorne zwierząt przeznaczonych do przejęcia i uboju w dniu następnym do godz. 10. W $1962 \mathrm{r}$. likwidację wieczornego karmienia rozszerzono na inne powiaty Lubelszczyzny. Zakłady te nie stosowały w ogóle pojenia trzody chlewnej ${ }^{19}$.

O złym traktowaniu zwierząt pisali również w 1962 r. kontrolerzy TOnZ w Poznaniu: „w kulturalnym Poznaniu [...] cierpią w zimę na deszczu, nocą około 2000 zwierząt, [...] zwierzęta te rycza, wołaja o pomoc, a bezmyślny człowiek, jak to wypowiedział dozorca zakładów w 1958 r.: "Panie, co się Pan tak upomina, one i tak będą zabite«. [...] Nadchodzi zima, na dworze bez dachu znajduje się 1500 zwierząt" Ten opis warunków w rzeźni poznańskich Zakładów Mięsnych dopełniały informacje o ich traktowaniu przez pracowników: „Jest przejmujące dżdżyste powietrze - pełne rampy zwierząt. Zwierzęta przebywaja w kojcach bez dachu po kilka dni. Przy wyładowaniu świń przy drugiej rampie używaja pracownicy nieprawidłowej rampy - deski bez poręczy - i na skutek tej wadliwej rampy świnie wypychane z pierwszego piętra wagonu wpadaja wprost ryjem na żelazną poręcz kojca. Na tę ilość zwierząt, pada kilka sztuk łamiąc nogi, miednice i inne kości”21.

Skandaliczne warunki traktowania zwierząt stwierdzono w $1962 \mathrm{r}$. w trakcie kontroli w Bazie Transportowej oraz Ubojowo-Eksportowej w Szczecinie. Także tutaj rampy były niedostosowane wysokościa do rozładunku zwierząt. Ich wyładowywanie odbywało się po gładkiej, pochylonej klapie samochodu, po której świnie się ślizgały i kaleczyły

18 AAN, NIK II, sygn. 33/279, Protokół kontroli w Zakładach Mięsnych w Białymstoku st. inspektora Zygmunta Leśniewskiego, 2 X-21 XI 1962 r., k. 45.

19 AAN, NIK II, sygn. 33/194, Protokół kontroli Zakładów Mięsnych w Lublinie w okresie 4 VI-12 VI 1962, przez inspektorów NIK, b.d.

${ }^{20}$ AIPN, sygn. 1585/22813, W. Chmielewski, Władysław Stawski, TOZ, Poznań, 8 XI 1962 r., k. 159.

${ }^{21}$ Tamże, SOS dla dręczonych przez człowieka zwierząt. TOZ Poznań, Wiktor Chmielewski, Poznań, 23 XI 1962 r. 
nogi w szparze pomiędzy klapą a podłogą wozu. Wózek do przewożenia kaleczonych świń nie posiadał odpowiednich pasów. Po zdjęciu ich z wózka ciagnięto je za ogon i uszy, wlokąc po bruku. Z braku elektrycznego poganiacza popędzanie zwierząt odbywało się wyłącznie za pomoca bicia guma i pałkami: „powszechnie stosowania jest praktyka kopania zwierząt z wykręcaniem bydłu ogonów”.

Zwierzęta przebywały w tylko częściowo krytych oborach od 3 do 10 dni. Większość dowożonego bydła nie mieściła się w nich i stała w zagrodach bez żadnej ochrony przed pogoda: „Zwierzęta stoją na bruku pokrytym mazią z kału, błota i moczu. Nie ma śladu podściółki ze słomy ani miału torfowego”. Kontroler, który w rzeźni spędził kilka dni, nigdy nie widział, „aby zwierzęta karmiono lub pojono”22.

W powiecie brzezińskim, według przedstawiciela TOnZ, w rzeźniach: „Duży procent świń łamie nogi lub otrzymuje inne obrażenia. Do świń opornych przy wyładunku konwojenci stosują wciskanie dwóch palców w oczy, przy czym świnia ulega i pada na ziemię"23.

Opisując w 1951 r. rzeźnię w Przeworsku, kontroler TOZ pisał: „Nie ma ogrodzenia dla przepędzania żywca od bucht wypoczynkowych do hali ubojowej, ponieważ rozgrodzenie parkaniku powoduje rozlatywanie się pędzonych sztuk po całym terenie. Robotnicy, uganiający się za rozpierzchłym się żywcem, zadają mu uszkodzenie cielesne biciem" ${ }^{4}$.

Okrucieństwo w traktowaniu świń przybierało niekiedy skrajną postać, jak we wspomnianym przez Wandę Falkowską w reportażu z 1968 r. przypadku jednego z pracowników rzeźni w Ełku, który kradł mięso w ten sposób, że wykrawał kawałki karczku z żywych zwierząt. Co prawda został ujęty, ale wiele takich przypadków nie było ujawnianych ${ }^{25}$.

Jednak najbardziej wstrząsające opisy postępowania ze zwierzętami w rzeźniach dotycza ich zabijania. Zgodnie z obowiąującymi przepisami zwierzę poddane ubojowi miało być najpierw ogłuszone. W przypadku bydła na przełomie lat pięćdziesiątych i sześćdziesiątych odbywać się to miało przy użyciu aparatu Radical - rodzaju pistoletu ze specjalnymi nabojami. W praktyce jednak stosowano często zupełnie inne metody.

${ }_{22}$ Tamże, Protokół z kontroli w Bazie Transportowej oraz Ubojowo-Eksportowej w Szczecinie przy ul. Wendy 1/3 przeprowadzonej w dniu 14, 17 i 18 września 1962 r. przez delegata TOnZ - Oddział w Szczecinie Jana Niemyskiego, b.d., k. 170.

${ }_{23}$ Tamże, TOnZ, Oddział w Brzezinach Łódzkich do komendanta MO w Brzezinach, Brzeziny, 20 IV 1959 r., k. 167.

${ }^{24}$ AAN, TOZ, sygn. 23, Zestawienie z kontroli rzeźni na terenie woj. lubelskiego przeprowadzonych w miesiącu marcu 1951 r. przez Rejonową Sekcję Inspektorów Zarządu Głównego Towarzystwa Ochrony Zwierząt w Lublinie, b.d., k. nlb.

${ }^{25}$ W. Falkowska, dz. cyt., s. 5. 
Pisali o tym m.in. autorzy memoriału wystosowanego przez Zarząd Główny TOnZ do ministra administracji publicznej Edwarda Osóbki-Morawskiego z lipca 1947 r. Wskazywali m.in. na to, że ubój zwierząt, poza dużymi miastami, odbywa się w sposób niehumanitarny. Oznaczało to, że nie stosowano tam wcześniejszego ogłuszania zwierząt przy użyciu aparatów elektrycznych i iglicowych. „W rzeźniach tych zwierzęta, podlegające ubojowi, również i konie, przed ich wykrwawieniem, w sposób nieudolny sa ogłuszane przy pomocy obuchów, wielokrotnie wymierzanych w głowę zwierzęcia (unikającego tych ciosów), czemu nieuchronnie towarzyszy wybijanie oczu, łamanie rogów przy nasadzie czaszki, wybijanie zębów itp. Nie ulega wątpliwości, że w tych warunkach zadaje się zwierzęciu zbędne przedśmiertne męczarnie, które muszą być uznane za zdecydowane barbarzyństwo".

Jeszcze gorzej było przy uboju potajemnym, prowadzonym na szeroką skalę „w każdym mieście czy osiedlu”, jak również w uboju rytualnym, „z którego mięso ukazuje się na rynku nielegalnym”. Do tych rzeźni, nieobjętych kontrola, trafiały w dużej części zwierzęta chore, transportowane „nocami, w stanie kompletnego wyczerpania, stłoczone $\mathrm{w}$ warstwach, skrępowane drutem, w wielu razach z połamanymi odnóżami, powybijanymi zębami i zakneblowanymi pyskami. Zwierzęta te, po przewiezieniu na miejsce kaźni, zrzucane sa z wysokich podwozi na bruk, i, o ile nie mają złamanych nóg, łamia je najczęściej przy upadku. Omdlałe z bólu i wyczerpane [...] przez katowanie dragami zmuszone do podniesienia się $\mathrm{z}$ bruku i w brutalny sposób pędzone, nieraz na trzech odnóżach lub wlokące swe okrwawione tułowia do zamaskowanej rzeźni” były następnie zabijane.

Autorzy memoriału upominali się również o ubój zwierząt na wsi, gdzie „panuja [...] w tej dziedzinie również jak najgorsze stosunki. [...]. Niemal w każdej wsi odbywa się ubój potajemny, uprawiany przez miejscowych spekulantów - rzeźników, skupujacych od gospodarzy zdrowe i chore sztuki, do wyrobów wędliniarskich, lokowanych następnie w miejscowych sklepach lub rozprowadzanych w dni targowe po małych miastach, miasteczkach i osiedlach. Ci sami domorośli rzeźnicy zabijaja świnie, jak i inne zwierzęta, u poszczególnych gospodarzy za pewnym wynagrodzeniem pieniężnym lub w naturze. Sposób zabijania zwierząt [...] zależnie od danej okolicy i przyjętego zwyczaju (ogłuszanie lub bez ogłuszania, czyli "na żywca») odbywa się w sposób okrutny, w dodatku na podwórkach i zazwyczaj w obecności asystujacych dzieci” ${ }^{26}$.

${ }^{26}$ AAN, TOZ, ZG TOnZRP do ob. Premiera, Ministra Administracji Publicznej Edwarda Osóbki-Morawskiego, Warszawa, 23 VII 1947 r., s. 14-16. 
Nawet jeżeli stosowano wzmiankowane urządzenie (Radical), to okazywało się, że ogłuszenie przy jego pomocy nie zawsze było skuteczne. W piśmie Delegatury Inspekcji Higieny we Wrocławiu do TOnZ Wrocław z 28 X 1958 r. wskazywano na liczne jego wady i ciagłe psucie się $^{27}$. Ponadto niektórzy pracownicy rzeźni nie umieli go obsługiwać lub czynili to nieudolnie i nieskutecznie ${ }^{28}$. Prace nad innym aparatem do ogłuszania bydła (,typu MOG”) trwały na początku lat sześćdziesiątych, ale brakowało pieniędzy na przeprowadzenie odpowiednich testów ${ }^{29}$. W wielu rzeźniach nie stosowano z różnych przyczyn elektrycznych kleszczy do ogłuszania świń ${ }^{30}$ albo te, których używano, nie powodowały dostatecznego oszołomienia: „Zwierzęta pomimo dłuższego nawet działania na nie prądem ginęły w pełni świadomości”31.

Jak w tej sytuacji odbywało się ogłuszanie, a potem zabijanie zwierząt? Kontrolerzy rzeźni w co prawda skapych i wyrywkowych opisach przedstawiaja przykłady ogromnego okrucieństwa. Z ich ustaleń wynika, że w wielu wypadkach w kontrolowanych zakładach było ono częściej normą niż ewenementem.

Kontroler rzeźni miejskiej we Wrocławiu pisał w 1962 r.: „na hali uboju leżała na wpół żywa krowa, która wykrwawiał robotnik [...]; drugi robotnik natomiast jednocześnie na żywca odrabywał rogi. Personalii [sic!] tego robotnika nie ustaliłem, ponieważ uciekł, a z pozostałej załogi nikt nie chciał ujawnić jego nazwiska. [...] Pragnę zwrócić uwagę na zachowanie się ob. G. i jego pomocnika podczas przeprowadzanego przez nich wykrwawiania krowy: odniosłam nieodparte wrażenie, że tego rodzaju sadystyczne uśmiercanie krowy sprawia im wielka przyjemność, ponieważ wykonywali tę czynność z drwiącymi i ironicznymi uśmiechami. Po każdym uderzeniu siekiery i noża krowa podnosiła

${ }^{27}$ AIPN, sygn. 1585/22813, MPSiS Delegatura Inspekcji Higieny we Wrocławiu do TOnZ, Wrocław, 28 X 1958 r., k. 198.

${ }_{28}$ Tamże, TOnZ, Oddział w Brzezinach Łódzkich do komendanta MO w Brzezinach, Brzeziny, 20 IV 1959 r., k. 167; tamże, Odpis protokołu z kontroli uboju w rzeźni w Chrzanowie przeprowadzonej przez członków Delegatury Sekcji Inspektorów w Krakowie 7 IV [19]59 o godz. 9.30, k. 185; tamże, Oddział we Wrocławiu do Powiatowej Rady Narodowej w Zgorzelcu, Wrocław, 10 VIII 1958 r., k. 190; tamże, Protokół z kontroli uboju w rzeźni w Chrzanowie przeprowadzonej przez Radziwiłł i Ryzner 7 IV 1959 r. o godz. 9.30 w obecności Kierownika Rzeźni, k. 193.

29 Tamże, Zarząd Główny TOnZ do ob. Henryka Chmielewskiego, Dyrektora Departamentu Społeczno-Administracyjnego MSW, Warszawa, 16 XII 1962 r., k. 154.

30 Tamże, TOnZ w PRL Oddział w Katowicach do ZG TOnZ w Polsce, Katowice, $23 \mathrm{~V} 1959 \mathrm{r}$.

31 Tamże, TOnZ Oddział we Wrocławiu do Powiatowej Rady Narodowej w Zgorzelcu, Wrocław, 10 VIII 1958 r., k. 190. 
głowę i wierzgała nogami, przy tym wydawała jęki”32. W Bazie Ubojowo-Eksportowej w Szczecinie w 1962 r. pędzenie bydła z zagród do hali ubojowej odbywało się „również za pomocą bicia i bolesnego wykręcania ogonów. Świnie bite są gumowymi rurami i kopane”. „Krowy i konie po wyprowadzeniu do hali ubojowej nie sa poddawane natychmiastowemu i równoczesnemu ubojowi, lecz wiązane do słupów, oczekują w długiej kolejce, przyglądając się kolejnej rzezi z przerażeniem. Zwierzętom przed ubojem nie zasłania się oczu"33.

W Krakowie podczas uboju koni w grudniu 1958 r. stwierdzono, że „aparaty »Radical« posiadane przez rzeźnię zepsuły się i konie dobijano siekiera (toporem); w dwóch aparatach pękły bolce, konie padły, lecz natychmiast wstały, zranione przez aparat, zaczęły rzucać się i męczyły się tak długo, aż zdołano je dobić toporem, co nastapiło dopiero po 3-4 uderzeniach w głowę". Stajnie znajdujące się w rzeźni zamieniono na magazyny i ubojnię królików, konie były zatem przetrzymywane w hali ubojowej i podczas uboju wykazywały „duże zdenerwowanie” ${ }^{4}$. Podobnie wyglądała sytuacja w tej rzeźni kilka miesięcy później: „Na hali ubojowej stwierdzono kilka zabitych koni, nie zostały zabite aparatem Radical, lecz uderzeniami toporem lub siekiera”. Uboju dokonywał G. Józef. Kierownik rzeźni wiele razy zwracał mu uwagę, że konie należy zabijać tym aparatem, ale „ob. G. jest uparty i woli bić toporem. [...] Konie żywe znajduja się w hali ubojowej podczas uboju i wykazuja wyraźne zdenerwowanie. Dwa konie znajdujace się na hali podczas kontroli drżały przez cały czas. Obecność żywych koni na hali ubojowej podczas uboju jest wbrew przepisom" 35 .

Zaalarmowany informacją o męczarniach zadawanych zwierzętom w rzeźni Powszechnej Spółdzielni Spożywców w Kątach k. Wadowic Oddział TOnZ w Katowicach informował swoją warszawska centralę: „Ogłuszanie bydła odbywa się wprawdzie aparatem Radical, ale tak nieudolnie, że bydło jest kaleczone, a następnie całkowicie jeszcze przytomne, ogłuszane dodatkowo młotem! Kleszcze do ogłuszania świń

${ }^{32}$ Tamże, Sprawozdanie z inspekcji przeprowadzonej w Rzeźni Miejskiej we Wrocławiu przy ul. Legnickiej w dniu 6.9.1962 przez inspektora TOZ J. Wypychowska w asyście pracownika Polskiego Radia ob. Łączyńskiego, Wrocław, 6 IX 1962 r., k. 156.

${ }_{33}$ Tamże, Protokół z kontroli w Bazie Transportowej oraz Ubojowo-Eksportowej w Szczecinie przy ul. Wendy 1/3 przeprowadzonej w dniu 14, 17 i 18 września $1962 \mathrm{r}$. przez delegata TOnZ - Oddział w Szczecinie Jana Niemyskiego, b.d., k. 171.

${ }^{34}$ Tamże, TOnZ w PRL Warszawa, Protokół z kontroli rzeźni koni w Krakowie na „Zabłociu” przeprowadzony przez Del. TOZ Radziwiłł i Wiśniewski Wł., Kraków, 20 XII 1958 r., k. 192.

${ }_{35}$ Tamże, Kraków, Protokół spisany 10 II 1959 podczas kontroli rzeźni koni w Krakowie przy ul. Zabłocie nr 13. 
nie mają transformatora, przez co są męczone niesamowicie. Zupełnie żywe, z połamanymi kręgosłupami podrzynane są w pełnej świadomości. Cielęta wieszane są głową na dół, a dopiero potem ogłuszane młotem”. W Chorzowie 10 VII 1958 r. do uboju dopędzano „większą ilość świń mieszczących się w jednym pomieszczeniu”. Ogłuszone przy użyciu kleszczy elektrycznych, przebijane nożem, nawet dające znaki życia były wrzucane do gorącej wody, gdzie kończyły swój żywot ${ }^{36}$.

To właśnie wymieniane po wielekroć pałka i młot były najpewniej najczęściej używanymi i często nieskutecznymi narzędziami do ogłuszania zwierząt.

Aby ten wstrząsający obraz dopełnić, trzeba wspomnieć o pochodzących z 1948 r. doniesieniach prasowych o tym, że w Toruniu „niedobite świnie wrzuca się do kotłów z wrzątkiem. Były nawet wypadki, że oszalałe z bólu zwierzęta wyrywały się i biegały po rzeźni. Niedawno doniesiono również z Chełma zwierzęta ogłusza się tam nieraz przez 10 minut drewnianym tłuczkiem. W wielu rzeźniach przywozi się bydło lub konie ze skrępowanymi nogami, a do uboju pędzi się, kopiąc i bijąc". Takie postępowanie było nie tylko naganne ze względów humanitarnych, ale miało również wpływać na pogorszenie gatunku mięsa. „Słonina przechodzi krwią i nie nadaje się na eksport" ${ }^{37}$.

Jaka była powszechność tych praktyk? Jak już wzmiankowano, nie jesteśmy w stanie tego ustalić na podstawie dotychczas przebadanych materiałów źródłowych. Z zachowanej sprawozdawczości TOnZ i NIK z kontroli rzeźni zdaje się wynikać, że opisane przypadki okrutnego traktowania zwierząt nie były czymś wyjątkowym, a częstotliwość stosowania tych praktyk wzrastała wraz z okresowymi „spiętrzeniami” dostaw bydła i trzody.

\section{Konkluzje}

Przeprowadzone kwerendy w poszukiwaniu materiałów zawierających informacje, na podstawie których można naszkicować obrazy ludzkiego okrucieństwa wobec zwierząt rzeźnych w Polsce na przełomie lat pięćdziesiątych i sześćdziesiątych XX w. dały stosunkowo najlepszy efekt w przypadku prasy i wybranych dokumentów przechowywanych

${ }^{36}$ AIPN, sygn. 1585/22813, TOnZ w PRL Oddział w Katowicach do ZG TOnZ w Polsce, Katowice, 23 V 1959 r.; W. Wernic, dz. cyt., s. 1.

37 Żywcem do kotta wrzucane świnie. Gdy brak naboi i dobrej woli rzeźników, „Wieczór” 1948, nr 45, s. 5. 
w archiwach centralnych. Nie sa one wyczerpujące i nie pozwalają na odpowiedź na pytanie o skale zachowań wzmiankowanych w odnalezionych opisach. Wiadomo jednak, że w analizowanych materiałach stosunkowo najczęściej wzmiankowano o tym okrucieństwie przy okazji opisów spędów i skupu zwierząt, ich transportu, ogłuszania i zabijania w rzeźniach. Zwierzęta były głodzone i pozbawianie picia, zbyt długo transportowane w upały lub mrozy, w niedostosowanych do tego wagonach lub samochodach. Wiele $z$ nich $z$ tych przyczyn padało. Te, które dotarły do rzeźni, musiały czekać na zabicie nierzadko w długiej kolejce, patrząc na śmierć innych zwierząt i wykazując w związku z tym objawy silnego napięcia i stresu. Ich zabijanie odbywało się w niehumanitarny sposób nawet $\mathrm{z}$ punktu widzenia obowiązujących wówczas $\mathrm{w}$ tym względzie procedur.

\section{Bibliografia}

Animal Revolution. Changing Attitudes toward Speciesism, Oxford 2000.

Bakke M., Studia nad zwierzętami. Od aktywizmu do akademii $i$ z powrotem?, „Teksty Drugie” 2011, nr 3, s. 193-204.

Człowiek $w$ relacji do zwierzat, roślin $i$ maszyn $w$ kulturze, t. 1: Aspekt posthumanistyczny $i$ transhumanistyczny, t. 2: Od humanizmu do posthumanizmu, red. J. Tymieniecka-Suchanek, Katowice 2014.

Domańska E., Historia w kontekście posthumanistyki, „Historyka. Studia Metodologiczne" 45, 2015, s. 5-21.

Nowak K., Animal studies - wyzwanie dla historiografii?, https://histmag.org/ Animal-studies-wyzwanie-dla-historiografii-3208 (27 II 2019).

Zwierzęta $i$ ich ludzie. Zmierzch antropocentrycznego paradygmatu, red. A. Barcz, D. Łagodzka, Warszawa 2015.

Dariusz Jarosz

Images of cruelty: preliminary research into the treatment of cattle and pigs in the Polish People's Republic at the turn of the 1950s and the 1960s (Summary)

The results of the research of archival sources and press publications used in the article show that abuse towards animals for slaughter was most often referenced in the accounts from their assembly, purchase, transport, and stunning and killing in slaughterhouses. The animals were starved and deprived of water, transported for excessive amounts of time in extreme heat or frost with the use of inadequate train cars or vehicles. Many animals died due to their 
mishandling. Those which made it to the slaughterhouse would often wait in long lines to be slaughtered, forced to look at the death of other animals and thus exposed to high levels of anxiety and stress. Their slaughter was often inhumane, even from the point of view of the erstwhile standards. Due to its preliminary character, the research described in the article does not allow to estimate how common it was to treat animals this way in the period in question.

Dariusz Jarosz - prof. dr hab., specjalista w zakresie historii społecznej Polski w latach 1944-1989 i stosunków PRL z Francja. Autor m.in.: Polacy a stalinizm 1948-1956, Warszawa 2000 (z Marią Pasztor); Afera mięsna. Fakty $i$ konteksty, Torun 2004 (z Marią Pasztor); Stosunki polsko-francuskie 1944-1980, Warszawa 2008 (z Maria Pasztor); „Zhańbiona” wieś Okót. Opowieści o buncie, Warszawa-Kielce 2016 (z Grzegorzem Miernikiem); Rzeczy, ludzie, zjawiska. Studia z historii spotecznej stalinizmu w Polsce, Warszawa 2017.

Dariusz Jarosz - PhD with habilitation, professor, expert in social history of Poland in the years 1944-1989 and relations between the Polish People's Republic and France. Author of such works as: Polacy a stalinizm 1948-1956, Warsaw, 2000 (co-authored with Maria Pasztor); Afera mięsna. Fakty i konteksty, Toruń, 2004 (co-authored with Maria Pasztor); Stosunki polsko-francuskie 1944-1980, Warsaw, 2008 (co-authored with Maria Pasztor); „Zhańbiona” wieś Okót. Opowieści o buncie, Warsaw-Kielce, 2016 (co-authored with Grzegorz Miernik); Rzeczy, ludzie, zjawiska. Studia z historii społecznej stalinizmu $w$ Polsce, Warsaw, 2017.

E-mail: darjarosz@wp.pl. 